\title{
Evaluation of Vocational Services Provided to Jordanian Disabled People According to International Standers
}

\author{
Alia Al-Oweidi ${ }^{1}$ \\ ${ }^{1}$ The World Islamic Science and Education University, Jordan \\ Correspondence: Alia Al-Oweidi, The World Islamic Science and Education University, Jordan. E-mail: \\ aliaart2001@yahoo.com
}

Received: September 12, 2014 Accepted: November 1, 2014 Online Published: February 25, 2015

doi:10.5539/ies.v8n3p77

URL: http://dx.doi.org/10.5539/ies.v8n3p77

\begin{abstract}
The purpose of the study is to evaluate the vocational rehabilitation services provided to people with disabilities according to international standards in Jordan. The sample of the study consisted of (56) managers and teachers in four specialized centers in vocational rehabilitation. The findings showed that the compatibility degree ranged between high and average levels, as findings show that the evaluation is high in center's philosophy, center's aims for vocational rehabilitation and training domains. Moreover, the evaluation was in an average level in assessment and diagnosis, vocational guidance and safety and security measures, interacting with local community, vocational rehabilitation staff and procedures as well as general activities. Meanwhile, the performance was low in shelter workshops and follow up domains. The findings show that the means are low regarding to visual impairment center on center's philosophy, assessment and diagnosis, shelter workshops and follow up domains while, there were no differences in the other domains attributed to disability type.
\end{abstract}

Keywords: vocational rehabilitation, disabled people, international standards, Jordan

\section{Introduction}

The governments and organizations of disabled realized the importance of taking care of disabled people in the society as well as focusing on the strength sides of this category of people in order to ensure a stable life for them. One of the aspects of this interest is the rehabilitation in all forms (medical, psychological, academic and vocational). Rehabilitation in its general sense means the development of the disabled person abilities to be independent, productive and adaptive. Moreover, it includes helping disabled people to overcome the negative effects of the disability as well as the psychological effects of this situation. Hamilton (1950) stated that rehabilitation is a process aiming to evaluate the positive abilities for the disabled person and developing it for his benefit (Jade \& Martz, 2010).

Providing disabled people with rehabilitation services has many advantages such as providing them with employment opportunities through training, integrating them in the community and achieving functional and body skills needed for independent life. Due to the importance of this concept many studies have been conducted to determine international quality standards in the vocational rehabilitation of disabled people (Dalal, Pande, Dhawan, \& Dwijendra, 2000).

The aim of this study is to explore the vocational rehabilitation services provided for disabled people in Jordan as well as its compatibility with international standards. The analytical descriptive approach will be used to answer the questions of the study. This study will deal with three domains, the concepts of rehabilitation, rehabilitating disabled people according to international standards in Jordan and its compatibility with international standards.

The need for rehabilitating disabled people had increased after the world's first and second wars as those wars caused many disabilities for a lot of people who needed training and qualification to achieve self independence (O'Reilly, 2003). The philosophy of vocational rehabilitation focuses on the disabled person as a human being that deserves to live independently with dignity and respect. Therefore, the disabled must be moved from depending on others to live independently and being accepted socially. Moreover, he must enjoy his social, human and employment rights as any other person (Al-Zomoot, 2011).

In 1993 the Arab labor organization had adopted the convention number (17) and the recommendation (7) 
regarding the standards of the vocational rehabilitation of disabled people to follow up with the international efforts in this field (Kishno, 2007).

The existence of international standard adopted by organizations confirms the importance of vocational rehabilitation of disabled people in a systematic order according to sequenced processes. Robin and Roessler (2011) mentioned that the procedures of vocational rehabilitation centers includes a set of standards that forms the main engine for all procedural steps carried out by the teams and the specialists.

\subsection{Problem of the Study}

The vocational rehabilitation centers for persons with disabilities is an important aspect to support people with disability in vocational, so that it is important to apply international standards for vocational rehabilitation. The researcher is aware that there are deficiencies in the application of international standards in vocational rehabilitation. This study seeks to identify weaknesses in the application in order to improve vocational rehabilitation services in centers to people with disabled.

The current study is seeking to answer the following questions:

1) What is the degree of applicability of international vocational rehabilitation standards on Jordanian vocational rehabilitation centers?

2) Are there any significant statistical differences at the level of $(\alpha<0.05)$ in the degree of applicability of international vocational rehabilitation standards on Jordanian vocational rehabilitation centers according to the difference in disability type ( mental, hearing and visual) disability in Jordan?

\subsection{Significance of the Study}

The importance of this study emerges from dealing with an important issue about disabled people in Jordan which is the vocational rehabilitation. Moreover, the study contributes in determining the steps and procedures of those centers and benefits the responsible people in those centers by increasing their knowledge with international standards of vocational rehabilitation in order to increase the effectiveness of Jordanian centers. The study also contributes to deviate procedures currently in vocational rehabilitation to identify weaknesses in centers to improve service delivery in the field of vocational rehabilitation.

a) Definition of vocational rehabilitation:

It is the process of providing training in a specific trade with the aim of gaining employment rehabilitation-the restoration of someone to a useful place in society (ALO, Recommendation 99, 1955).

The aim of vocational rehabilitation of disabled people is to enable them from using their mental, social and physical abilities and this requires a comprehensive plan within a team of multi-speculated fields (Rubin \& Roessler, 2001). However, despite the differences in the definitions of this concept it has common elements such as:

1) The disability which prevent the disabled person from living independently.

2) It is a kind of medical, psychological, social and educational rehabilitation.

3) The general aim of vocational rehabilitation is helping the disabled person to regain his abilities in order to keep living in his society.

4) The processes are benefiting both individuals and communities.

5) It is a process of sequenced integrated and systematic procedures.

b) Importance of work for disabled people:

The disabled person is just as any normal person wishes to work and desires a work opportunity in community. $\mathrm{He} / \mathrm{she}$ capable of accomplishing a lot, Therefore, the importance of work for him/ her represented in: Providing the main requirements of life: through work, so he/she can starts a family and enjoy independence (Larsoon \& Gard, 2003).

c) Vocational Rehabilitation of disabled people in Jordan:

Though the rehabilitation of disabled people starts in 1939 in Jordan since the establishment of blinds' school in Jerusalem, the real and organized services are still new. This development starts with the efforts of voluntary organizations then public ones. Therefore, the development in special education was a combined effort between voluntary and public sectors.

With regard to the vocational rehabilitation of the disabled people it starts in the 1906s as there were (3) centers 
specialized in this kind of rehabilitation, one of them is holy lands organization for the deaf (1964) followed by the Swedish organization for individual relief (1968). In the 1970s there were nine centers such as, Vocational and employment center in Rusyfa, Muslim youth center, Saudi center for blind and Al-Hussein center for mobility disabilities. The number of centers increase to (13) centers such as Nazek Al-hariri for mental disability, Vocational and employment center in Irbid. While, the 1990s witnesses a dramatic increase as the centers tootled (23) all over the country (Ministry of social affairshttp://www.mosd.gov.jo/).

d) Vocational Rehabilitation standards of Disabled People

The vocational rehabilitation standards are a set of practical and organizational procedures organizing the vocational rehabilitation of people with disabilities; those procedures are consistent with the recommendations and conventions issued by the international labor organization and the Arab labor organization.

There are many studies in the field of vocational rehabilitation such as Homa (2004) which aimed to investigate the characteristics of the people who are lucky in receiving vocational assessment services. The findings showed that visual and hearing disabilities are less luck than motor disability and severe disabilities are less lucky than medium and low disabilities.

Beveridge and Fabiary (2007) studied the relationship between the goals of individual vocational training plan and functional outcome of the program. The findings showed that achieving job satisfaction of the disabled person gives a higher degree of effectiveness for the vocational training program and this gives him a greater opportunity in finding the suitable job.

Boutain (2006) studied the outcomes of the Vocational Rehabilitation program for people with hearing loss. Specifically, the study explored the effectiveness of the VR program on consumers who are deaf and hard of hearing with regard to amount of public assistance. The findings showed Significant differences were found indicating relationships between (a) public assistance, degree of hearing loss, and the reception of college and university training, (b) VR services and competitive employment, (c) type of occupation and degree of hearing loss, (d) earnings, degree of hearing loss, and the reception of college and university training, (e) number of hours worked, degree of hearing loss, and the reception of college and university training, (f) previous collegiate experience and competitive employment, and (g) secondary disabilities and competitive employment. Implications for practitioners and rehabilitation counselor educators are included.

Hein (2005) investigated the views of clients regarding vocational rehabilitation programs. The findings showed that the most important procedures that must be done to achieve satisfaction are listening to the client and understanding job conditions as well as honesty and respect.

Diee (2008) Build a Model for the International Vocational Rehabilitation Standards and the Range of Applying it on the Vocational Rehabilitation Centers at Kuwait State. In order to achieve this purpose, reviewing and analyzing the International recommendations and agreements have been, which are related to the disabled persons in general, in addition to those related to the vocational rehabilitation of the disabled persons in particular. In addition to the theoretical Literature in this field, the study results showed the Degree of applying the international Standards of the vocational rehabilitation for the disabled persons in two centers of vocational rehabilitation in Kuwait to be in a lower level.

\section{Methodology}

Descriptive Methodology used to describe the vocational rehabilitation services to disabled people according to international standers. The population of the study consisted of managers and teachers working in public and private vocational rehabilitation disabled centers in Jordan. The sample of the study consisted of (56) managers and teachers working in four centers in Jordan (36 females and 20 males). The researcher used (Al-Diee, 2008) scale as he developed an international standards scale for disabled people rehabilitation after reviewing the related literature and the international labor organization recommendation. The tool is scaled according to five-likert scale as follows:

$4=$ Applied in a high degree.

$3=$ Applied in an average degree.

$2=$ Applied in a low degree.

$1=$ Doesn’t apply. 
Table 1. Domains and items of the scale

\begin{tabular}{lll}
\hline No & Scale domains & Items \\
\hline 1 & Center's philosophy for vocational rehabilitation & $1-7$ \\
2 & Center's aims for vocational rehabilitation & $8-16$ \\
3 & Assessment and diagnosis & $17-27$ \\
4 & Vocational guidance & $28-36$ \\
5 & Vocational training & $37-49$ \\
6 & Work and employment & $50-67$ \\
7 & Shelter workshops & $68-73$ \\
8 & Follow up & $74-83$ \\
9 & Safety and security measures & $84-93$ \\
10 & Vocational rehabilitation staff & $94-99$ \\
11 & Interacting with local community & $100-110$ \\
12 & Procedures and general activities & $111-119$ \\
\hline
\end{tabular}

\subsection{Reliability and Validity}

Validity was established through content validity, the instrument was standardized on the response of a experts group $(n=5)$ in Educational faculty at Jordan university. Raters gave their comments on the scale. Meanwhile, reliability of the instrument was determined through a pilot study; sample of 50 respondents from of the study population. The results were as follows:

Table 2. Pearson coefficients and Cronbach's alpha coefficients

\begin{tabular}{llcc}
\hline No & Scale domains & Pearson coefficients Test Retest & Cronbach's alpha \\
\hline 1 & Center's philosophy for vocational rehabilitation & 0.90 & 0.74 \\
2 & Center's aims for vocational rehabilitation & 0.82 & 0.84 \\
3 & Assessment and diagnosis & 0.85 & 0.81 \\
4 & Vocational guidance & 0.80 & 0.89 \\
5 & Vocational training & 0.82 & 0.85 \\
6 & Work and employment & 0.96 & 0.92 \\
7 & Shelter workshops & 0.91 & 0.89 \\
8 & Follow up & 0.96 & 0.88 \\
9 & Safety and security measures & 0.95 & 0.75 \\
10 & Vocational rehabilitation staff & 0.91 & 0.83 \\
11 & Interacting with local community & 0.90 & 0.62 \\
12 & Procedures and general activities & 0.92 & 0.95 \\
\hline & Total & 0.92 & 0.85 \\
\hline
\end{tabular}

The results of reliability show that it's range (0.80-0.96) by test Retest, and (0.62-0.95) on Cronbach alpha.

\section{Results}

What is the degree of applicability of international vocational rehabilitation standards on Jordanian vocational rehabilitation centers?

To answer this questions means were calculated according to the following criteria:

Means less than (2) refer to low applicability degree. 
Means ranged between (2-3) refer to average applicability degree.

Means more than (3) refer to high applicability degree.

Table 3. Reponses means for the degree of applicability of international vocational rehabilitation standards on Jordanian vocational rehabilitation centers

\begin{tabular}{lll}
\hline Scale domains & Means & Applicability degree \\
\hline Center's philosophy for vocational rehabilitation & 3.51 & High \\
Center's aims for vocational rehabilitation & 3.06 & High \\
Assessment and diagnosis & 2.85 & Average \\
Vocational guidance & 3.20 & High \\
Vocational training & 3.21 & High \\
Work and employment & 2.38 & Average \\
Shelter workshops & 1.62 & Low \\
Follow up & 1.92 & Low \\
Safety and security measures & 3.23 & High \\
Vocational rehabilitation staff & 2.79 & Average \\
Interacting with local community & 2.70 & Average \\
Procedures and general activities & 2.88 & Average \\
\hline
\end{tabular}

The findings showed that the applicability degree is ranged between high average and low. The findings indicated that the applicability is high in center's philosophy for vocational rehabilitation domains, while it is in an average level in assessment and diagnosis, Work and employment, vocational rehabilitation staff, Interacting with local community and procedures and general activities domains meanwhile, it was low in shelter workshops and follow up domains.

Table 4. Mean and standard deviations for center's philosophy domain

\begin{tabular}{llll}
\hline Item & M & SD & $\begin{array}{c}\text { Applicability } \\
\text { degree }\end{array}$ \\
\hline $\begin{array}{l}\text { The center adopts a clear written philosophy for the vocational rehabilitation } \\
\text { of the disabled }\end{array}$ & 3.54 & 0.63 & High \\
$\begin{array}{l}\text { The center sets out in providing vocational rehabilitation of the disabled from } \\
\text { the public social responsibility }\end{array}$ & 3.46 & 0.74 & High \\
$\begin{array}{l}\text { The center believes that the main role is transforming disabled from } \\
\text { dependence to self-dependence as possible }\end{array}$ & 3.64 & 0.67 & High \\
$\begin{array}{l}\text { The center observes all the rights of the disabled regardless gender or } \\
\text { disability }\end{array}$ & 3.43 & 0.83 & High \\
$\begin{array}{l}\text { The center provides vocational rehabilitation free for all disability categories } \\
\text { The center adopts a clear definition for vocational rehabilitation of disabled } \\
\text { extracted from international standards }\end{array}$ & 3.75 & 0.51 & High \\
\hline
\end{tabular}

Table 4 shows that the means ranged from (3.21-3.75) as the highest mean was for the item provided that (The center provides vocational rehabilitation free for all disability categories) and the lowest was for (The center adopts a clear definition for vocational rehabilitation of disabled extracted from international standards). In general, the total mean was (3.51) showing a high applicability degree. 
Table 5. Mean and standard deviations for center's goals domain

\begin{tabular}{llll}
\hline Item & M SD & $\begin{array}{l}\text { Applicability } \\
\text { degree }\end{array}$ \\
\hline $\begin{array}{l}\text { Rehabilitating and qualifying work abilities of the disabled for the highest } \\
\text { point }\end{array}$ & 3.54 & 0.69 & High \\
$\begin{array}{l}\text { Rehabilitant of injured people to enable them from continuing work } \\
\text { Assessing and diagnosing disabled to determine their rehabilitation according }\end{array}$ & 3.07 & 1.04 & High \\
to their abilities and readiness & 0.68 & High \\
Training disabled people on jobs fitting their status & 3.61 & 0.56 & High \\
Directing disabled people on jobs fitting their status & 3.54 & 0.63 & High \\
Employing disabled people on jobs fitting their status & 2.86 & 0.75 & Average \\
Providing shelter work for disabled people & 1.95 & 0.92 & Low \\
Follow up with employed disabled people to ensure their continuity & 2.50 & 0.99 & Average \\
Integrating disabled peopled socially & 3.39 & 0.78 & High \\
\hline
\end{tabular}

Table 5 shows that the means ranged between (2.04-3.61) as the highest mean was for item (Training disabled people on jobs fitting their status) and the lowest was for (Providing shelter work for disabled people). In general, the total mean was (3.06) showing a high applicability degree.

Table 6. Mean and standard deviations for assessment and diagnosis domain

\begin{tabular}{|c|c|c|c|}
\hline Item & M & SD & $\begin{array}{l}\text { Applicability } \\
\text { degree }\end{array}$ \\
\hline The center uses special forms for assessment and diagnosis & 3.18 & 0.94 & High \\
\hline $\begin{array}{l}\text { The Center studies first models of assessment and diagnosis accompanied by } \\
\text { supporting documents before the assessment and diagnosis of a disabled person }\end{array}$ & 3.21 & 1.06 & High \\
\hline $\begin{array}{l}\text { The Center interviews the disabled person for the purposes of assessment, } \\
\text { diagnosis and determines eligibility. }\end{array}$ & 3.43 & 0.91 & High \\
\hline $\begin{array}{l}\text { The Center conducts an interview with the family of a disabled person to } \\
\text { collect information needed to assess, diagnosis and determine eligibility. }\end{array}$ & 3.43 & 0.91 & High \\
\hline $\begin{array}{l}\text { The center conducts a comprehensive assessment and diagnosis (medical, } \\
\text { social, psychological and educational }\end{array}$ & 2.89 & 1.15 & Average \\
\hline The center conducts a comprehensive assessment and diagnosis for the disabled & 2.79 & 1.19 & Average \\
\hline $\begin{array}{l}\text { The center conducts psychological tests for the disabled to ensure his fitness for } \\
\text { work }\end{array}$ & 2.64 & 1.27 & Average \\
\hline $\begin{array}{l}\text { The center uses tests and multiple scales (psychological, social, and } \\
\text { educational) to assess, diagnose and determine the eligibility of a disabled } \\
\text { person. }\end{array}$ & 3.04 & 1.06 & High \\
\hline $\begin{array}{l}\text { The disabled is required to provide his school records or any other information } \\
\text { regarding work experiences }\end{array}$ & 3.50 & 0.87 & High \\
\hline
\end{tabular}

Table 6 showed that the means ranged between (2.64-3.50) as the highest mean was for (The disabled is required to provide his school records or any other information regarding work experiences) while, the lowest mean was for (The center conducts psychological tests for the disabled to ensure his fitness for work). In general, the total mean was (2.85) showing an average applicability degree. 
Table 7. Mean and standard deviations for vocational guidance domain

\begin{tabular}{|c|c|c|c|}
\hline Item & $\mathrm{M}$ & $\mathrm{SD}$ & $\begin{array}{l}\text { Applicability } \\
\text { degree }\end{array}$ \\
\hline $\begin{array}{l}\text { Vocational rehabilitation specialist makes sure that the disabled person had a } \\
\text { medical examination before the implementation of any professional guidance to } \\
\text { him. }\end{array}$ & 3.46 & 0.91 & High \\
\hline $\begin{array}{l}\text { Verifying physical ability of a disabled person in terms of the professional } \\
\text { treatment and the possibility of improving that capability }\end{array}$ & 3.29 & 0.93 & High \\
\hline Verifying his personal and family conditions before guidance & 3.11 & 0.78 & High \\
\hline $\begin{array}{l}\text { Vocational rehabilitation specialist analyzes the results of the assessment and } \\
\text { diagnosis in order to take advantage of them in guiding the disabled person } \\
\text { towards the right career }\end{array}$ & 3.25 & 0.96 & High \\
\hline $\begin{array}{l}\text { Vocational rehabilitation specialist uses the assistant of the family while } \\
\text { directing the disabled person. }\end{array}$ & 3.32 & 0.97 & High \\
\hline $\begin{array}{l}\text { Vocational rehabilitation specialist Provides for disabled people the opportunity } \\
\text { to express his views about the desired professions }\end{array}$ & 3.29 & 0.93 & High \\
\hline $\begin{array}{l}\text { Vocational rehabilitation specialist Provides for disabled people during } \\
\text { vocational guidance information on the functions and requirements and the } \\
\text { needs of the labor market }\end{array}$ & 2.89 & 1.15 & High \\
\hline $\begin{array}{l}\text { The vocational rehabilitation specialist Determines appropriate profession based } \\
\text { on the information that has been collected for a disabled person }\end{array}$ & 3.29 & 0.85 & High \\
\hline $\begin{array}{l}\text { The vocational rehabilitation specialist prepared an individual plan based on the } \\
\text { information that has been collected for the disabled person }\end{array}$ & 2.79 & 1.09 & Average \\
\hline
\end{tabular}

Table 7 showed that the means ranged between (2.89-3.46) as the highest means was for (Vocational rehabilitation specialist makes sure that the disabled person had a medical examination before the implementation of any professional guidance to him) while, the lowest was for (The vocational rehabilitation specialist prepared an individual plan based on the information that has been collected for the disabled person). In general, the total mean was (3.20) showing a high applicability degree.

Table 8. Mean and standard deviations for vocational training domain

\begin{tabular}{llll}
\hline Item & M & SD & $\begin{array}{l}\text { Applicability } \\
\text { degree }\end{array}$ \\
\hline $\begin{array}{l}\text { The Center trains disabled person in a consistent manner with individual } \\
\text { vocational rehabilitation plan that has been prepared }\end{array}$ & 3.25 & 0.96 & High \\
$\begin{array}{l}\text { The Center applies the principles and methods used in vocational rehabilitation } \\
\text { training of normal people on disabled people }\end{array}$ & 3.07 & 1.04 & High \\
$\begin{array}{l}\text { The Center applies the principles and methods used in vocational rehabilitation } \\
\text { training of normal people on disabled people }\end{array}$ & 3.25 & 0.84 & High \\
$\begin{array}{l}\text { The center keeps the continuity of vocational training for the disabled person to } \\
\text { acquire the necessary skills to work }\end{array}$ & 3.39 & 0.87 & High \\
$\begin{array}{l}\text { The center provides a suitable environment for the training of disabled persons } \\
\text { professionally, so that such an environment can be supportive of their individual } \\
\text { needs }\end{array}$ & 3.50 & 0.69 & High \\
$\begin{array}{l}\text { Center uses the curriculum in vocational rehabilitation suitable for ages, } \\
\text { abilities and preparations and concerns and needs of people with disabilities } \\
\begin{array}{l}\text { Center uses some of the people with disabilities who have been rehabilitated in } \\
\text { the professionally trained people Disabled others. }\end{array}\end{array}$ & 3.18 & 1.01 & High \\
\hline
\end{tabular}


The center provides opportunities for people with disabilities to demonstrate and utilize their creative, artistic and intellectual abilities during training

The center contributes to the training of people with disabilities professionally with normal people

The center trains people with disabilities professionally individually and collectively

The center provides workshops equipped with the tools and equipment necessary for the training of people with disabilities in various skills

The center provides workshops and training workshops for people with disabilities similar to those that train the normal people

The Center encourages employers to provide vocational training for people with disabilities in their work places as a training field in addition to theoretical training they receive at the center

\section{$3.251 .00 \quad$ High}

$2.46 \quad 1.13 \quad$ Average

$3.43 \quad 0.78 \quad$ High

$3.43 \quad 0.83$ High

$3.36 \quad 0.94$ High

$3.14 \quad 0.88$ High

Table 8 shows that the means of this domain ranged between (2.64-3.50) as the highest mean was for (The center provides a suitable environment for the training of disabled persons professionally, so that such an environment can be supportive of their individual needs) while, the lowest mean was for (The center contributes to the training of people with disabilities professionally with normal people). In general, the total mean of this domain is (3.21) showing a high applicability degree.

Table 9. Mean and standard deviations for employment domain

\begin{tabular}{|c|c|c|c|}
\hline Item & M & SD & $\begin{array}{l}\text { Applicability } \\
\text { degree }\end{array}$ \\
\hline $\begin{array}{l}\text { The center makes sure that the disabled person in moved to labor market after } \\
\text { rehabilitation }\end{array}$ & 2.43 & 0.95 & Average \\
\hline $\begin{array}{l}\text { The center overcomes all the difficulties preventing disabled people from } \\
\text { working in the labor market }\end{array}$ & 2.57 & 0.91 & Average \\
\hline The center registers disabled people in the civil services bureau & 1.96 & 1.03 & Low \\
\hline $\begin{array}{l}\text { The employment application provided by the centers includes all the } \\
\text { professional skills and needs of the disabled person }\end{array}$ & 2.18 & 1.15 & Average \\
\hline $\begin{array}{l}\text { The center organizes meeting with employers and disabled people before } \\
\text { working }\end{array}$ & 2.25 & 1.00 & Average \\
\hline $\begin{array}{l}\text { The Center encourages employers to contact the Civil Services to find out } \\
\text { about job vacancies they have and that can be for people with disabilities. }\end{array}$ & 2.32 & 1.05 & Average \\
\hline $\begin{array}{l}\text { The center contacts or visit employers to explain the work abilities and skills of } \\
\text { disabled people }\end{array}$ & 2.75 & 1.07 & Average \\
\hline $\begin{array}{l}\text { The center contributes in making modifications in the jobs of disabled people } \\
\text { as needed }\end{array}$ & 2.61 & 1.06 & Average \\
\hline The center helps disabled people to end employment procedures & 2.71 & 1.14 & Average \\
\hline $\begin{array}{l}\text { The center contributes in checking the work environment of the disabled } \\
\text { person }\end{array}$ & 2.18 & 1.15 & Average \\
\hline $\begin{array}{l}\text { The center contributes in providing qualified people to get jobs near their } \\
\text { homes }\end{array}$ & 2.50 & 0.91 & Average \\
\hline $\begin{array}{l}\text { The center contributes in preventing discrimination against disabled people if } \\
\text { their work is equal to normal people work }\end{array}$ & 2.86 & 1.20 & Average \\
\hline The center contributes in providing qualified people to get jobs in their homes & 2.04 & 0.95 & Average \\
\hline $\begin{array}{l}\text { The center cooperates with civil services and employers to keep jobs fitting } \\
\text { disabled people. }\end{array}$ & 2.04 & 0.95 & Average \\
\hline
\end{tabular}


The center follow up the commitment of employers to employ $2 \%$ of disabled people

The Center checks employment guides to find suitable jobs for disabled people

The center conducts researches on disabled people performance (production, satisfaction, injuries, absence, stability)

The center contributes in finding jobs for disabled with normal people

\section{$2.25 \quad 1.10 \quad$ Average}

2.251 .03 Average

$2.21 \quad 1.02 \quad$ Average

$2.68 \quad 1.05$ Average

Table 9 showed that the means of this domain ranged between (1.96-2.86) as the highest mean was for (The center contributes in preventing discrimination against disabled people if their work is equal to normal people work) while, the lowest was for (The center registers disabled people in the civil services bureau). In general, the total mean of this domain is (2.38) showing an average applicability degree.

Table 10. Mean and standard deviations for shelter workshops domain

\begin{tabular}{llll}
\hline Item & M & SD & $\begin{array}{l}\text { Applicability } \\
\text { degree }\end{array}$ \\
\hline $\begin{array}{l}\text { The center provides vocational rehabilitation for multi-disabled people and } \\
\text { severe disabilities }\end{array}$ & 2.36 & 1.09 & Average \\
$\begin{array}{l}\text { The center provides special procedures related to training and working in } \\
\text { protected environment for disabled people who can't do competitive regular }\end{array}$ & 2.04 & 1.16 & Average \\
work & & Low \\
$\begin{array}{l}\text { The center applies legal regulations regarding wages and work conditions in } \\
\text { shelter workshops }\end{array}$ & 1.89 & 0.91 & Low \\
$\begin{array}{l}\text { The center provides shelter workshops for disabled people who can't go to work } \\
\text { The center provides directed medical supervision for disabled people in shelter } \\
\text { workshops }\end{array}$ & 1.68 & 0.81 & Low \\
$\begin{array}{l}\text { The center provides for people with disabilities working in shelter workshops } \\
\text { opportunities for advancement and career adjustment with the possibility of } \\
\text { moving to open work }\end{array}$ & 1.75 & 0.84 & Low \\
\hline
\end{tabular}

Table 10 showed that the means of this domain ranged between $(1.68-2.36)$ as the highest mean was for (The center provides vocational rehabilitation for multi-disabled people and severe disabilities) while, the lowest was for (The center provides shelter workshops for disabled people who can't go to work). In general, the total mean of this domain is (1.62) showing low applicability degree.

Table 11. Mean and standard deviations for follow up domain

\begin{tabular}{|c|c|c|c|}
\hline Item & $\mathrm{M}$ & SD & $\begin{array}{l}\text { Applicability } \\
\text { degree }\end{array}$ \\
\hline $\begin{array}{l}\text { The center follow up people with disabilities qualified professionally after } \\
\text { their employment }\end{array}$ & 2.18 & 0.97 & Average \\
\hline $\begin{array}{l}\text { The Center prepares reports about the status of a disabled person after } \\
\text { employment }\end{array}$ & 1.93 & 1.01 & Low \\
\hline $\begin{array}{l}\text { The Center Investigates the satisfaction of professionally qualified disabled } \\
\text { person after employment }\end{array}$ & 2.25 & 1.07 & Average \\
\hline $\begin{array}{l}\text { The center checks the effectiveness of vocational training services provided to } \\
\text { a disabled person after employment }\end{array}$ & 2.14 & 0.96 & Average \\
\hline $\begin{array}{l}\text { The Center follows up over the receipt of a disabled person for all of his rights } \\
\text { after the being employed }\end{array}$ & 1.75 & 1.07 & Low \\
\hline
\end{tabular}


The Center works to remove barriers (spatial and administrative) that prevent the stability of a disabled person in his post

The Center listens to employers' comments and people with disabilities on vocational training and the problems they face in their jobs

The center contributes in providing in-service training for the disabled person when needed

The center provides working opportunities for other disabled people if they wish to leave the current work

The Center contributes in providing technological means to assist a disabled person qualified professionally at work
$2.07 \quad 1.17 \quad$ Average

$2.46 \quad 1.19 \quad$ Average

$2.71 \quad 1.14 \quad$ Average

$2.36 \quad 1.21 \quad$ Average

$2.07 \quad 1.11 \quad$ Average

Table 11 showed that the means of this domain ranged between $(1.75-2.71)$ as the highest mean was for (The center contributes in providing in-service training for the disabled person when needed) while, the lowest was for (The Center follows up over the receipt of a disabled person for all of his rights after the being employed). In general, the total mean of this domain is (1.92) showing low applicability degree.

Table 12. Mean and standard deviations for safety and security procedures domain

\begin{tabular}{|c|c|c|c|}
\hline Item & M & SD & $\begin{array}{l}\text { Applicability } \\
\text { degree }\end{array}$ \\
\hline $\begin{array}{l}\text { The Center designs buildings and facilities in accordance with the standards of } \\
\text { safety and security internationally accredited }\end{array}$ & 3.04 & 1.16 & High \\
\hline The Center puts directing signs at all its facilities & 3.18 & 1.08 & High \\
\hline Entrances and exits of buildings are clear and easily accessible and use & 3.44 & 0.84 & High \\
\hline The Center and its services places are away from the congestion of population & 2.96 & 1.22 & Average \\
\hline The center provides good lightening and ventilation & 3.39 & 0.98 & High \\
\hline $\begin{array}{l}\text { Workshops and training classes are suitable taking into account the } \\
\text { circumstances and needs of persons with disabilities }\end{array}$ & 3.11 & 1.15 & High \\
\hline There are fire alarming devices & 3.43 & 0.99 & High \\
\hline $\begin{array}{l}\text { Bathrooms design in the center are in a way that fit the requirements of people } \\
\text { with disabilities and their use }\end{array}$ & 3.18 & 1.05 & High \\
\hline $\begin{array}{l}\text { The center has the needed technical staff for maintenance and security } \\
\text { procedures }\end{array}$ & 3.18 & 1.01 & High \\
\hline Trainers and Trainees move easily inside the center & 3.36 & 0.94 & High \\
\hline
\end{tabular}

Table 12 showed that the means of this domain ranged between (2.96-3.43) as the highest mean was for (There are fire alarming devices) while, the lowest was for (The Center and its services places are away from the congestion of population). In general, the total mean of this domain is (3.23) showing high applicability degree

Table 13. Mean and standard deviations for vocational training staff domain

\begin{tabular}{|c|c|c|c|}
\hline Item & M & SD & $\begin{array}{l}\text { Applicability } \\
\text { degree }\end{array}$ \\
\hline There are sufficient numbers of qualified employees in the center & 3.00 & 1.11 & High \\
\hline $\begin{array}{l}\text { The center has specialized employees in many fields to ensure the } \\
\text { comprehensive vocational rehabilitation }\end{array}$ & 3.14 & 0.88 & High \\
\hline $\begin{array}{l}\text { The services are provided through co-operative team within many fields } \\
\text { (medical, social, psychological, special education and vocational rehabilitation) }\end{array}$ & 2.86 & 1.03 & Average \\
\hline
\end{tabular}


The center provides financial and moral support for the employees

The administration trains the employees in specialized fields to cope with the developments in disabled people vocational rehabilitation

The center forms working committees including employees, disabled people, employers and families

\section{$2.82 \quad 1.18 \quad$ Average}

$2.57 \quad 1.06 \quad$ Average

$2.32 \quad 1.11 \quad$ Average

Table 13 showed that the means of this domain ranged between (2.32-3.14) as the highest mean was for (The center has specialized employees in many fields to ensure the comprehensive vocational rehabilitation) while, the lowest was for (The center forms working committees including employees, disabled people, employers and families). In general, the total mean of this domain is (2.79) showing an average applicability degree.

Table 14. Mean and standard Deviations for interacting with local community domain

\begin{tabular}{|c|c|c|c|}
\hline Item & $\mathrm{M}$ & $\mathrm{SD}$ & $\begin{array}{l}\text { Applicability } \\
\text { degree }\end{array}$ \\
\hline $\begin{array}{l}\text { The center holds seminars and conferences for vocational rehabilitation to } \\
\text { educate members of the community in this field }\end{array}$ & 2.93 & 1.14 & Average \\
\hline $\begin{array}{l}\text { The center cooperate with the institutions of the local community by announcing } \\
\text { its services with the aim of raising the level of awareness of the rights of persons } \\
\text { with disabilities and the possibility of rehabilitation professionally }\end{array}$ & 3.07 & 1.01 & High \\
\hline $\begin{array}{l}\text { The center encourages volunteer efforts (individual and institutional) and } \\
\text { estimated it highly }\end{array}$ & 3.04 & 1.06 & High \\
\hline $\begin{array}{l}\text { The center pursuit's development plans of community and qualifies people with } \\
\text { disabilities professionally in the same direction of these plans }\end{array}$ & 2.46 & 1.09 & Average \\
\hline $\begin{array}{l}\text { The center contributes in collaboration with persons with disabilities and their } \\
\text { families, employers and organizations of persons with disabilities to propose } \\
\text { legislations for vocational rehabilitation }\end{array}$ & 2.50 & 1.19 & Average \\
\hline $\begin{array}{l}\text { The center collaborates with persons with disabilities and their families, } \\
\text { employers and organizations of persons with disabilities in identifying trends and } \\
\text { priorities and to participate in the planning, implementation and evaluation of } \\
\text { vocational rehabilitation services }\end{array}$ & 2.46 & 1.13 & Average \\
\hline $\begin{array}{l}\text { The center provides advisory services and technical services of relevant } \\
\text { vocational rehabilitation for people with disabilities in the local community }\end{array}$ & 2.75 & 1.03 & Average \\
\hline $\begin{array}{l}\text { The center starts reciprocal and cooperative relations with vocational } \\
\text { rehabilitation centers for people with disabilities other existing locally, regionally } \\
\text { and internationally }\end{array}$ & 2.75 & 1.10 & Average \\
\hline $\begin{array}{l}\text { The center starts cooperative relationships with educational institutions at all } \\
\text { levels and in the community, regional and international levels }\end{array}$ & 2.96 & 1.44 & Average \\
\hline $\begin{array}{l}\text { The Center contributes to the organization of vocational rehabilitation programs, } \\
\text { especially for the disabled persons in the home }\end{array}$ & 1.87 & 1.62 & Low \\
\hline
\end{tabular}

Table 14 showed that the means of this domain ranged between (1.87-3.07) as the highest mean was for (The center cooperate with the institutions of the local community by announcing its services with the aim of raising the level of awareness of the rights of persons with disabilities and the possibility of rehabilitation professionally) while, the lowest was for (The Center contributes to the organization of vocational rehabilitation programs, especially for the disabled persons in the home). In general, the total mean of this domain is (2.70) showing an average applicability degree. 
Table 15. Mean and standard deviations for general activities procedures domain

\begin{tabular}{llll}
\hline Item & M & SD & $\begin{array}{c}\text { Applicability } \\
\text { degree }\end{array}$ \\
\hline $\begin{array}{l}\text { The center conducts research and studies to evaluate and improve vocational } \\
\text { rehabilitation services for people with disabilities in general }\end{array}$ & 2.32 & 1.15 & Average \\
$\begin{array}{l}\text { Provides work procedures to ensure that the benefit of persons with disabilities } \\
\text { of all vocational rehabilitation services available }\end{array}$ & 2.82 & 1.01 & Average \\
$\begin{array}{l}\text { The center offers financial assistance for people with disabilities through } \\
\text { joining the center }\end{array}$ & 3.11 & 1.02 & High \\
$\begin{array}{l}\text { The center provides free transportation service to and from the center for } \\
\text { disabled people }\end{array}$ & 3.07 & 1.20 & High \\
$\begin{array}{l}\text { The center contributes in protecting the disabled person from losing and aids or } \\
\text { social assistance obtained from other parties when joining the center }\end{array}$ & 3.00 & 1.01 & High \\
$\begin{array}{l}\text { The center follow and apply rules and recommendations of international } \\
\text { organizations and private vocational rehabilitation for people with disabilities }\end{array}$ & 2.96 & 1.09 & Average \\
$\begin{array}{l}\text { The center reviews the policies of vocational rehabilitation for people with } \\
\text { disabilities periodically. }\end{array}$ & 2.89 & 1.02 & Average \\
$\begin{array}{l}\text { The Center contributes to the training of people with disabilities on skills to } \\
\text { enable them to defend their professional issues } \\
\begin{array}{l}\text { The center provides some recreational activities and entertainment for disabled } \\
\text { people }\end{array}\end{array}$ & 3.57 & 0.91 & Average \\
\hline
\end{tabular}

Table 15 showed that the means of this domain ranged between (2.32-3.21) as the highest mean was for (The center provides some recreational activities and entertainment for disabled people) while, the lowest was for (The center conducts research and studies to evaluate and improve vocational rehabilitation services for people with disabilities in general). In general, the total mean of this domain is (2.88) showing an average applicability degree.

Table 16. Means, standard deviation and ANOVA values for disability category variable

\begin{tabular}{llllll}
\hline Domain & Disability category & M & F & Sig & F \\
\hline \multirow{4}{*}{ Center Philosophy } & Deaf & 3.70 & & & \\
& Mental & 3.69 & & & \\
& Blind & 3.25 & 6.27 & 0.004 & 6.27 \\
& Total & 3.51 & & & \\
& Deaf & 3.15 & & & \\
Center objectives & Mental & 3.29 & & & \\
& Blind & 2.97 & 2.51 & 0.09 & 2.51 \\
& Total & 3.11 & & & \\
Assessment and diagnosis & Deaf & 3.00 & & & \\
& Mental & 3.73 & & & \\
& Blind & 2.91 & 6.92 & 0.002 & 6.92 \\
Vocational guidance & Total & 3.15 & & & \\
& Deaf & 3.22 & & & \\
& Mental & 3.60 & 3.61 & 0.03 & 3.61 \\
& Blind & 2.94 & & & \\
\hline
\end{tabular}




\begin{tabular}{|c|c|c|c|c|c|}
\hline \multirow{5}{*}{ Vocational training } & Total & 3.20 & \multirow{5}{*}{2.32} & \multirow{5}{*}{0.10} & \multirow{5}{*}{2.3} \\
\hline & Deaf & 3.06 & & & \\
\hline & Mental & 3.52 & & & \\
\hline & Blind & 3.15 & & & \\
\hline & Total & 3.21 & & & \\
\hline \multirow{4}{*}{ Employment } & Deaf & 2.34 & \multirow{4}{*}{0.43} & \multirow{4}{*}{0.65} & \multirow{4}{*}{0.43} \\
\hline & Mental & 2.54 & & & \\
\hline & Blind & 2.31 & & & \\
\hline & Total & 2.38 & & & \\
\hline \multirow{4}{*}{ Shelter work } & Deaf & 1.70 & \multirow{4}{*}{5.57} & \multirow{4}{*}{0.006} & \multirow{4}{*}{5.57} \\
\hline & Mental & 2.50 & & & \\
\hline & Blind & 1.74 & & & \\
\hline & Total & 1.92 & & & \\
\hline \multirow{4}{*}{ Follow-up } & Deaf & 2.03 & \multirow{4}{*}{4.12} & \multirow{4}{*}{0.02} & \multirow{4}{*}{4.12} \\
\hline & Mental & 2.74 & & & \\
\hline & Blind & 1.99 & & & \\
\hline & Total & 2.19 & & & \\
\hline \multirow{4}{*}{ Safety and security procedure } & Deaf & 2.83 & \multirow{4}{*}{2.74} & \multirow{4}{*}{0.07} & \multirow{4}{*}{2.74} \\
\hline & Mental & 3.34 & & & \\
\hline & Blind & 3.45 & & & \\
\hline & Total & 3.23 & & & \\
\hline \multirow{4}{*}{ Vocational rehabilitation staff } & Deaf & 2.43 & \multirow{4}{*}{2.36} & \multirow{4}{*}{0.10} & \multirow{4}{*}{2.36} \\
\hline & Mental & 3.00 & & & \\
\hline & Blind & 2.93 & & & \\
\hline & Total & 2.79 & & & \\
\hline \multirow{4}{*}{ Interacting with local community } & Deaf & 2.53 & \multirow{4}{*}{2.55} & \multirow{4}{*}{0.08} & \multirow{4}{*}{2.55} \\
\hline & Mental & 3.11 & & & \\
\hline & Blind & 2.58 & & & \\
\hline & Total & 2.70 & & & \\
\hline \multirow{4}{*}{ Procedures and general activities } & Deaf & 2.80 & \multirow{4}{*}{0.80} & & \\
\hline & Mental & 3.10 & & 0.45 & 080 \\
\hline & Blind & 2.82 & & & \\
\hline & Total & 2.88 & & & \\
\hline
\end{tabular}

Table 16 showed that the performance differences according to disability category was low for visual disability on center's philosophy for vocational rehabilitation, assessment and diagnosis, Vocational guidance and follow up domains. Meanwhile, there were no differences in the other domains. The findings showed that the means on vocational rehabilitation staff domain were better on visual disability than hearing disability. Further, the performance means of procedures and general activities domain were better for hearing disability than visual disability.

\section{Discussion}

The findings the applicability degree of the standards ranged between high, average and low. The findings showed that the evaluation is high in center's philosophy, center's aims for vocational rehabilitation and training 
domains. This can be attributed to the administrative procedures related to the philosophy and aims of the center that must be approved before starting work by the ministry of social development in Jordan. Moreover, the management of the center tries to achieve the goals through its activities. Moreover, the nature of the samples Reponses (trainers) may lead to a high degree of applicability in the rehabilitation domains.

Moreover, the evaluation was in an average level in assessment and diagnosis, vocational guidance and safety and security measures, interacting with local community, vocational rehabilitation staff and procedures as well as general activities while, the performance was low in shelter work domain. It is clear that the centers suffer from weakness in the comprehensive assessment in all fields as this assessment is the approach to the vocational rehabilitation for the disabled. Mostly, centers use an interview as there are some strength points to assess the case.

In the field of vocational guidance there is a strength point that the center takes into consideration the desire of the disabled person to work according to his disability limits. However, some trainers show weakness in identifying the suitable jobs available in the labor market as well as the new developments in this field. Moreover, vocational rehabilitation centers train disabled people far from normal people since they are specialized in working with disabled people and this reduces the integration principles of the disabled.

In the field of employment, there is a shortage in linking disabled people with civil services bureau to facilitate their employment. Moreover, the center doesn't follow up the extent of organizations' commitment to employ $4 \%$ of disabled people. The findings showed that the follow up still weak and this can be explained that those centers focus on training in service and don't follow up with trainees after being employed or even checks their satisfaction about their jobs. There are no follow up for their rights or safety measures even the buildings designs and the availability of safety equipment are not observed by those centers. Another risky indicator is that those centers are existed in heavily populated areas and this confuses the movement of disabled people.

The findings showed that the rate of trainees to trainers is acceptable as there are (6) trainees for each trainer. Each center has specialists in many fields working cooperatively. However, the teams need more cooperation and harmony since their cooperation in an average level and this can be due to the weak management or the lack of training courses, this can be attributed to the management style the depends on the ministry's training courses. All this reduces the interaction with the family especially if we know that families have their own responsibilities, lack of education and the economical problems of families.

With regard to the interaction of vocational rehabilitation centers the findings showed that it is in an average level in educating people about disability and a low level in the field of rights and laws since the centers do nothing in this field. There is no communication between centers so there is no experiences exchange. Another problem is the shortage in keeping with movement disabilities so this type of disability has no suitable consideration.

With regard to procedures and general activities, findings show that the degree of applicability is in an average level and this is due to the weakness of staff procedures and steps of scientific research, also signals the results to the weak position in the application of the provisions and recommendations of the organizations because of poor follow-up staff of administrative and technical items and international updates. However, the results indicated high index applicable in respect of the financial aid they are backed by the state, most center offering a sum of money to the trainees for training, and that the centers provide services free transportation to and from the center, but this service is available for females but not for males, and this is a burden on the family a disabled male, because it will be a transfer to and from the center every day.

With regard to the second question the findings showed that the means are low for the visual disability on center's philosophy for vocational rehabilitation, assessment and diagnosis, Vocational guidance and follow up domains. Meanwhile, there were no differences in the other domains. The findings showed that the means on vocational rehabilitation staff domain were better on visual disability than hearing disability. Further, the performance means of procedures and general activities domain were better for hearing disability than visual disability. This may be referred to the nature of the disability that needs more attention than other disabilities.

The results of this study is similar to (Homa, 2004) which indicate that the vocational rehabilitation services is less than other impairments, and the results of this study is similar to (Diee, 2008) which indicate that the international vocational criteria is low in Kuwait. Also some parts of results of study similar to Beveridge and Fabiary (2007) which showed that achieving job satisfaction of the disabled person gives a higher degree of effectiveness for the vocational training program. 


\section{Conclusion}

The results of this study show that the managers who work with disabled should plan future strategies and to achieve shelter work for disabled people this because of deficient in this area. Also the vocational rehabilitation centers should follow up with disabled people after training, and Conducting programmed meetings with their families to obtain feedback about qualifying and training disabled in this field. In addition, the vocational rehabilitation centers of disabled people should Reviewing the most recent standards as well as international conventions regarding professional qualification. Do more studies in the field of vocational rehabilitation centers. Also this study suggest to adapting the international standards for the vocational rehabilitation centers for the disabled by the Ministry of Social Development in Jordan and providing qualified personnel and specialized in the field of vocational rehabilitation and the provision of educational and training programs. Finally, the rehabilitation vocational centers should Apply standards of safety and security and Conduct a field study to reveal the extent of suitable buildings and work centers for people with disabilities and ways to adapt building.

\section{References}

Al-Zomoot, Y. (2011). Vocational Rehabilitation of the Disabled. Amman: Dar Al-fikr.

Beveridge, S., \& Fabian, E. (2007). Vocational Rehabilitation Outcomes: Relationship Between Individualized Plan for Employment Goals and Employment Outcomes. Rehabilitation Counseling Bulletin, 50(1), 46-54. Retrieved from http://rcb.sagepub.com/content/44/1/10.short?rss=1\&ssource=mfc

Boston, Q., \& Vaughn, M. (2010). Predicting employment outcomes among women of color with psychiatric disabilities. Journal of Vocational Rehabilitation, 33, 27-37. Retrieved from http://gradworks.umi.com/33/81/3381418.html

Boutin, D. (2006). Effectiveness of the State Vocational Rehabilitation Program for Consumers with Hearing Impairments (Unpublished doctoral dissertation). The Pennsylvania State University, Pennsylvania, USA.

Dalal, A. K, Kumar, S., \& Gokhale, D. (2000). Participatory Evaluation of CBR Projects in India. Project Report, University of Allahabad. Allahabad.

Diee, A. (2009). Build a Model for the International Vocational Rehabilitation Standards and the Range of Applying it on the Vocational Rehabilitation Centers at Kuwait State (Ph.D Dissertation, The University of Jordan, Amman, Jordan).

Gilbride, D. (2000). Employers Attitudes toward Hiring Person with Disabilities and Vocational Rehabilitation Services. The Journal of Rehabilitation, 60(3), 102-119.

Hein, S., Lustig, D., \& Uruk, A. (2005). Consumers Recommendation to Improve Satisfaction with Rehabilitation Services. Rehabilitation Counseling Bulletin, 49(1), 29-39. http://dx.doi.org/10.1177/00343552050490010401

Homa, D. (2004). The Impact of Vocational Evaluation on Outcomes in the Vocational Rehabilitation Services Program (Unpublished doctoral dissertation). Illinois Institute of Technology. Chicago, USA.

Jade, Y., \& Martz, E. (2010). Predictors of employment among individuals with disabilities: A Bayesian analysis of the Longitudinal Study of the Vocational Rehabilitation Services Program. Journal of Vocational Rehabilitation, 32, 35-45.

Kishno, M. (2007). Rights of Disabled Students in Work through labor international and Arabic Standards. Conference of social and professional Integration of the disabled. Ministry of Social Affairs, Kuwait, 18-28 Nov, 1-14.

Larsson, A., \& Gard, G. (2003). How Can the Rehabilitation Planning Process at the Workplace Be Improved? A Qualitative Study From Employers' Perspective. Journal of Occupational Rehabilitation, 3(13), 169-181. http://dx.doi.org/10.1023/A:1024953218252

O’Reilly, A. (2003). The Right to Decent Work of Persons with Disabilities. Geneva: ILO.

Obied, M. (2007). Rehabilitation Disabled. Amman: Dar Safa'a Publishers.

Rubin, S., \& Roessler, R. (2001). Foundations of the Vocational Rehabilitation Process. Austin: Pro-ed.

Scharle, A, (2011). Integrated Employment and Rehabilitation Services. Revista de Asistență Socială, 3, 67-75. 


\section{Copyrights}

Copyright for this article is retained by the author(s), with first publication rights granted to the journal.

This is an open-access article distributed under the terms and conditions of the Creative Commons Attribution license (http://creativecommons.org/licenses/by/3.0/). 